\title{
DEEP SEA MANGANESE NODULES THE CHALLENGE SINCE "CHALLENGER"
}

by

Eugen Seibold

\begin{abstract}
The discovery of deep sea manganese nodules in the nineteenth century led marine geologists into a continuing debate on their origin and formation. During the last decade, problems such as finding the most economical method of recovering nodules containing valuable amounts of copper, nickel, cobalt and other metals have posed a challenge not only to scientists but also to technologists, economists and even lawyers. Dr. Seibold reviews, from a geologist's point of view, the general features of the nodules, the current problems facing scientists who are studying them, and the worldwide economic implications of this exciting area of research.
\end{abstract}

\section{Introduction}

The first deep sea manganese nodules were recovered southwest of Canary Islands during H.M.S. CHALLENGER's pioneer cruise of 1872-1876. The now classic "Challenger Reports" contained many careful descriptions of the shape, growth features, nuclei and dredged sediments of the discovered nodules (see Figs. 1,2); they also earned the occasional critical rebuke:

The first volume recording the adventure of the CHALLENGER yachting trip is now out, and the other fifty-nine will be ready in less than a century. Everybody knows that Mr. Lowe sent a man-of-war away laden with Professors, and that these learned individuals amused themselves for four years. They played with thermometers, they fished at all depths from two feet to three miles; they brought up bucketfuls of stuff from the deep sea bottom; and they all puttered about and imagined they were furthering the grand Cause of Science. Then the tons of rubbish were brought home, and the genius who bossed the excursion proceeded to employ a swarm of foreigners to write monographs on the specimens. There were plenty of good scientific men in England, but the true philosopher is nothing if not cosmopolitan; so the taxpayers' money was employed in feeding a mob of Germans and other aliens. (Deacon, 1971).

The "feeding of scientists with taxpayer's money", however, led to a series of fundamental publications about manganese nodules, some with careful chemical analyses -

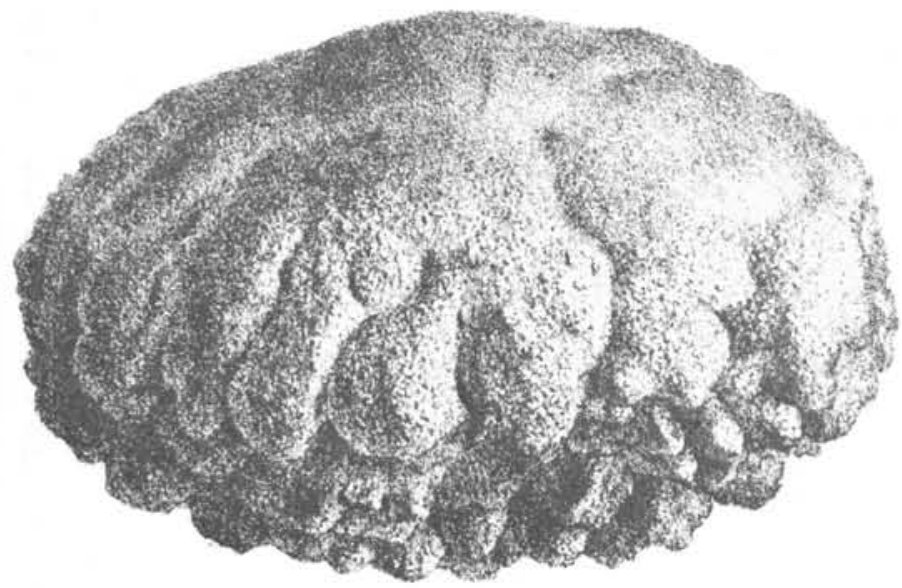

Figure 1: Specimen (actual size) of one of about 100 nodules recovered from a water depth of $5000 \mathrm{~m}$ at the Central Pacific CHALLENGER station 274; note the upper smooth and lower mammilated sides (from Murray \& Renard, 1891).
Thomson, 1874; Murray, 1876; Irvine, 1894. The formation of the nodules posed an attractive problem. Highly turbulent, submarine springs were considered to be a cause of the oolite-like internal structures. The chemical components were thought to have come from decomposed basic volcanic material, directly from seawater, or after "diagenetic" decomposition of sulfates and precipitation of metalsulfides which were later oxidized. $\mathrm{Cu}, \mathrm{Ni}$ and $\mathrm{Co}$ were usually present "in traces only", but Gumbel (1878) reported values for $\mathrm{Cu}$-oxide $(0.023 \%)$ and $\mathrm{Ni}$-Co-oxides $(0.012 \%)$ in the Pacific nodules recovered from a depth of $5500 \mathrm{~m}$.

A variety of such questions and even bacterial activity associated with nodules were thought to be important by the first authors, and the debate on the nodules' origin continues today (see Glasby, 1977 and Dreyfus-Rawson and Ryan, 1978 for recent summaries).

\section{Distribution of nodules}

The general distribution of manganese nodules on the sea floor, based on numerous photographs and sampling, is illustrated in Figure 3 (after Calvert, 1978). The distribution of sampling locations, however, is not uniform: gaps exist, for example, in the Indic and the southeastern Pacific. In general, however, areas with low sedimentation rates, such as the Pacific, show the greatest abundance of nodules, par-

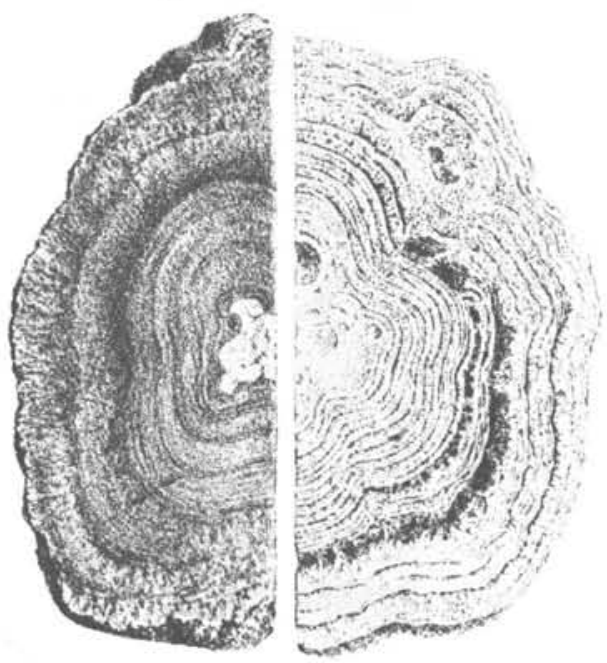

Figure 2: Sliced section (parallel to the sea bottom) of the upper part of a north Pacific nodule (actual size) showing internal layering and nuclei. The upper surface was covered with many epibenthic animals, particularly rhizopod and worm tubes (at CHALLENGER station 253, $5700 \mathrm{~m}$ water dépth, in Murray \& Renard, 1891). 
ticularly as compared to the Atlantic or Indic (both of which absorb large rivers and contain turbidites), or the deep sea basins which are below calcite compensation depth. Red clay or siliceous oozes most commonly form the underlying sediments. Bottom currents preventing sedimentation of terrigenous and biogenous particles, or even eroding them, are responsible for the nodule fields on Blake Plateau and off South Africa. The Antarctic circumpolar current may be the controlling mechanism for the nodule zone around $60^{\circ} \mathrm{S}$. It is thought that the flow of Antarctic bottom water causes the asymmetric distribution in the Atlantic.

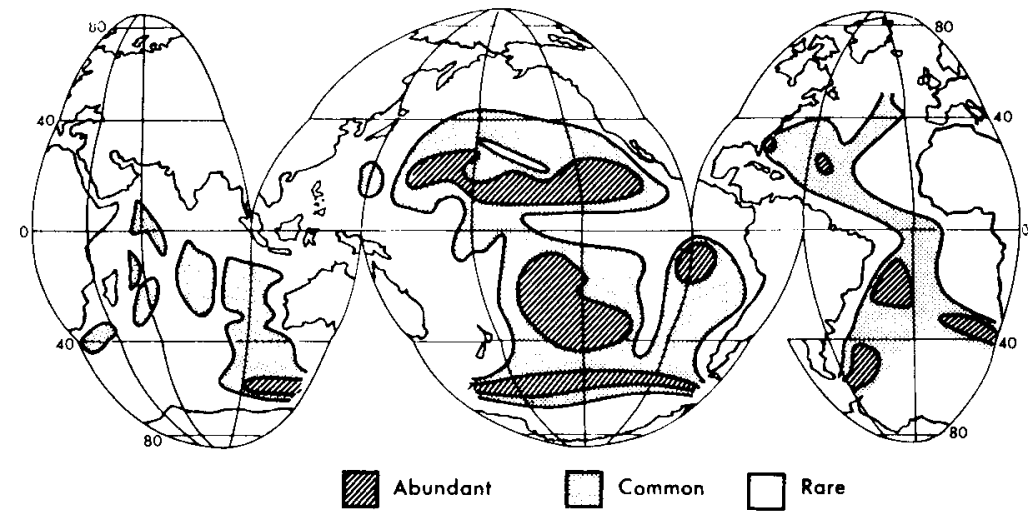

Figure 3: Distribution of manganese nodules in the world's oceans.

These very general statements are based upon present oceanic conditions and do not take into account fluctuations of the past. Nevertheless they serve as first "clues" for prospecting and are as useful as the general rule "oil can be expected in sedimentary basins". But where does one initially search for abundances of more than $10 \mathrm{~kg}$ of wet nodules $/ \mathrm{m}^{2}$ on the surface of the sea floor? (This is the quantity that is considered to be economically attractive if the nodules meet a minimal metal grade.)

Archer (1976) tried to convert population densities from sea floor photographs or television observations to abundances, and estimated a total sea bottom area of 23 million $\mathrm{km}^{2}$ with more than $10 \mathrm{~kg}$ nodules $/ \mathrm{m}^{2}$. This is a rough estimate because the conversion calculations depend on nodule sizes and sometimes size distributions are not published. Furthermore, any extrapolation from just a few stations suffers because of the "patchiness" of nodule occurrences. Sometimes high populations are reported to be uniform for many tens of kilometers. Variations between $23 \%$ to $50 \%$ over distances of a few kilometers to even a few meters are now common (Moore and Heath, 1966, Schultze-Westrum, 1973, Seibold, 1973 and Bezrukov, 1976).

The origin of patchiness is not well understood. Local sedimentation patterns, depending on topography and currents, proximity of volcanic sources for nodule nuclei or other factors, have been debated. Rocky seamounts and parts of the Blake Plateau are covered by encrustations. We have still much to learn before we can predict the optimal occurrence of nodule fields of "ore grade". One of the most intriguing questions has been why $90 \%$ populations did not grow together to form continuous pavements in deep sea basins, at least locally.

\section{Exterior and interior features}

Nodule sizes vary from $0.5 \mathrm{~cm}$ to several meters, but most frequently have diameters of several centimeters, rather like potatoes. Poly-nodules (agglomerations) are often observed. Micronodules, distributed generally in the sediments, are normally less than $1 \mathrm{~mm}$ in diameter. The bimodal size distributions still remain unexplained.

Nodule surfaces may vary in extremes from smooth to mammilated-knobby. Some have a smooth upper surface and a botryoidal lower surface (Fig. 1), suggesting different mechanisms of accretion or even dissolution (Raab, 1972).

They commonly contain a core or nucleus, such as the proverbial shark's tooth, fresh or altered volcanics, or fragments of older nodules. Sometimes a nucleus is not detectable, which influences the metal contents. High latitude fields (Fig. 3) may suffer from the dilution effect of nuclei from glacial drift materials.

Detailed studies of the nodules' interior characteristics reveal a complex growth history with only one common feature - the non-uniformity of deposition (Sorem and Fewkes in Glasby, 1977). Major layers, more or less concentric and 1/4-1 mm thick (Fig. 2) may consist of massive, mottled, columnar or laminated zones with different metal contents. Much work has yet to be done to decipher the periods and areal extents in the pulsations of deposition, non-deposition or even dissolution of nodule layers.

Nodule minerals point to further gaps in our knowledge. Randomly oriented microcrystalline intergrowths of manganese and iron hydroxides pose difficult analytical and technological problems, for here the classic physical mineral separation methods fail. Energy consuming pyro-metallurgical (smelting) or hydrometallurgical (leaching) methods have to be applied. The most common minerals seem to be manganese $\left(\mathrm{Mn}^{4+}\right)$ oxides such as todorokite or birnessite. Disordered phases include $\delta-\mathrm{MnO}_{2}$ and ferric oxyhydroxides (Burns \& Burns in Glasby, 1977). Apparently, todorokite occurs preferentially in deep sea basins and nodules with high $\mathrm{Mn} / \mathrm{Fe}-$ ratios, and is generally combined with higher $\mathrm{Ni}, \mathrm{Cu}$ and $\mathrm{Zn}$ contents. Birnessite, together with $\delta-\mathrm{MnO}_{2}$, however, is thought to be more abundant in sea mount nodules with lower $\mathrm{Mn} / \mathrm{Fe}$ ratios and higher Co-contents. More refined analytical techniques will contribute to the continuing debate on these findings.

Nodule porosities (primary by growth and secondary by diagenesis) may reach $60 \%$; consequently, average wet bulk densities are only about $1.95-2.0 \mathrm{~g} / \mathrm{cm}^{3}$ compared to densities of sediments of $1.2-1.5 \mathrm{~g} / \mathrm{cm}^{3}$. These high porosities are interesting technologically: nodule material is used to absorb carbon monoxide fumes from car exhausts or sulphur dioxide from power plants and also to extract materials from crude petroleum; they aid leaching processes as well. Up until now, however, most of the economic interest has centred on the content of valuable metals such as $\mathrm{Cu}, \mathrm{Ni}$ and $\mathrm{Co}$ in the nodules.

\section{Composition}

Table 1 offers some figures on the metal contents in nodules as reported in the literature. It should be noted that most of the averages given are based on only a few values compared to the huge areas involved, and that different analytical methods were used to arrive at these figures.

$\mathrm{Mn} / \mathrm{Fe}$ ratios illustrate the different mobilities of these elements. Reducing conditions favour both the mobility of $\mathrm{Mn}^{2+}$ and $\mathrm{Fe}^{2+}$, but $\mathrm{Fe}^{2+}$ ions are more easily fixed if $\mathrm{S}$ ions are available. Manganese, therefore, escapes more readily from sediments near continental borderlands and is relatively enriched in accretions there (Table 1, columns 1 and 2). Highly oxidyzing environments on seamounts (column 3) or in abyssal areas (column 4) are examples of the reverse. Nevertheless, the higher general mobility of manganese can be demonstrated by comparing deep sea sediments (column 5) with nodules (column 4).

In nodules beyond continental margins, $\mathrm{Mn}$ contents correlate with $\mathrm{Cu}$ and $\mathrm{Ni}$ contents positively, but negatively with Fe contents. Abyssal nodules (column 4) are therefore enriched in $\mathrm{Cu}$ and $\mathrm{Ni}$ as compared to seamount nodules (column 3). Whether Co contents always correlate positively with $\mathrm{Fe}$ contents is debatable, but if this was so, it could explain the high Co contents in seamount nodules (column 3 ). 
TABLE 1

\begin{tabular}{|c|c|c|c|c|c|c|c|c|c|c|}
\hline & 1 & 2 & 3 & 4 & 5 & 6 & 7 & 8 & 9 & 10 \\
\hline \multirow[t]{2}{*}{$\begin{array}{l}\text { Metals } \\
\text { (weight \%) }\end{array}$} & \multicolumn{3}{|c|}{$\begin{array}{l}\text { Manganese nodules and other } \\
\text { ferromanganese oxides }\end{array}$} & \multirow[t]{2}{*}{$\begin{array}{l}\text { Abyssal } \\
\text { nodules }\end{array}$} & \multirow{2}{*}{$\begin{array}{c}\text { Deep sea } \\
\text { sediments } \\
\text { Pacific }\end{array}$} & \multirow[t]{2}{*}{$\begin{array}{l}\text { Sea water } \\
(\mu \mathrm{g} / \mathrm{kg})\end{array}$} & \multicolumn{4}{|c|}{ Clarion - Clipperton prime area } \\
\hline & $\begin{array}{c}\text { Word ocean } \\
\text { average }\end{array}$ & $\begin{array}{l}\text { Continental } \\
\text { borderlands }\end{array}$ & $\begin{array}{c}\text { Sea } \\
\text { mounts }\end{array}$ & & & & Summary & 2 stations & $\begin{array}{c}\text { Dredge } \\
\text { haul }\end{array}$ & $\begin{array}{l}\text { Box } \\
\text { corer }\end{array}$ \\
\hline Samples & & 7 & 15 & 166 & & & 48 & 61 & 11 & 8 \\
\hline Mn & 16.17 & 36.69 & 14.62 & 16.78 & 1.25 & 2 & - & $19.8-29.4$ & $17.9-29.4$ & $\begin{array}{l}21.6 \\
-23.6\end{array}$ \\
\hline $\mathrm{Fe}$ & 15.61 & 1.34 & 15.81 & 17.27 & 6.50 & 10 & - & $5.3-12.4$ & $5.1-7.3$ & $\begin{array}{r}12.2 \\
-15.8\end{array}$ \\
\hline $\mathrm{Ni}$ & 0.489 & 0.121 & 0.351 & 0.540 & 0.029 & 2 & $0.1-1.93$ & $0.84-1.52$ & $1.00-1.60$ & $\begin{array}{c}0.63 \\
-0.82\end{array}$ \\
\hline Co & 0.299 & 0.011 & 1.15 & 0.256 & 0.012 & 0.03 & $0.01-0.50$ & $0.10-0.41$ & $0.15-0.30$ & $\begin{array}{c}0.30 \\
-0.38\end{array}$ \\
\hline $\mathrm{Cu}$ & 0.256 & 0.082 & 0.058 & 0.370 & 0.057 & 2 & $0.1-1.65$ & $0.36-1.31$ & $0.86-1.93$ & $\begin{array}{c}0.44 \\
-0.53\end{array}$ \\
\hline $\mathrm{Mn} / \mathrm{Fe}$ & 1.04 & 28.8 & 0.92 & 0.97 & 0.19 & 0.2 & - & - & - & - \\
\hline $\mathrm{Mn} / \mathrm{Cu}$ & 63 & 447 & 252 & 45 & 22 & 1 & - & - & - & - \\
\hline
\end{tabular}

Sources: Columns 1-4: Cronan in Glasby, 1977; Column 5: Elderfield in Glasby, 1977; Column 6: Murray and Brewer in Glasby, 1977; Column 7: Archer in Glasby and Katz, 1976; Column 8: Hartmann and Muller in Fanning and Mannheim (in press); Column 9: Gundlach and Marchig in Friederich, 1975; Column 10: Lange in Friederich, 1975.

Similarly, it is still not known whether the quantities of incorporated valuable metal are more dependent on mineralogy or on adsorption processes.

At present, metal contents of more than about $2 \%$ combined $\mathrm{Ni}, \mathrm{Cu}$ and $\mathrm{Co}$ are regarded as the economically attractive minimum for a mining "cut off". Only certain parts of the abyssal nodule fields (column 4), averaging $1.17 \%$, can be considered as prime areas. The selection of areas again suffers from high variations, and by "chemical patchiness". Table 1 includes metal contents of nodules from the most promising area between the Clarion and Clipperton fracture zones in the eastern equatorial Pacific. This area is located around $10^{\circ} \mathrm{N}$, covering some $200 \mathrm{~km}$ in width and more than $1000 \mathrm{~km}$ in length. Variations in metal content are very high (Table 1, column 7), even in a test field there (VALDIVIA Area 4) measuring about $800 \mathrm{~km}^{2}$ (column 8). Variations decrease in single dredge hauls (column 9: VALDIVIA Station 04-54) but are present even in box core samples with surfaces of $50-100 \mathrm{~cm}^{2}$ (column 10: VALDIVIA Station 04-26, and Fig. 4).

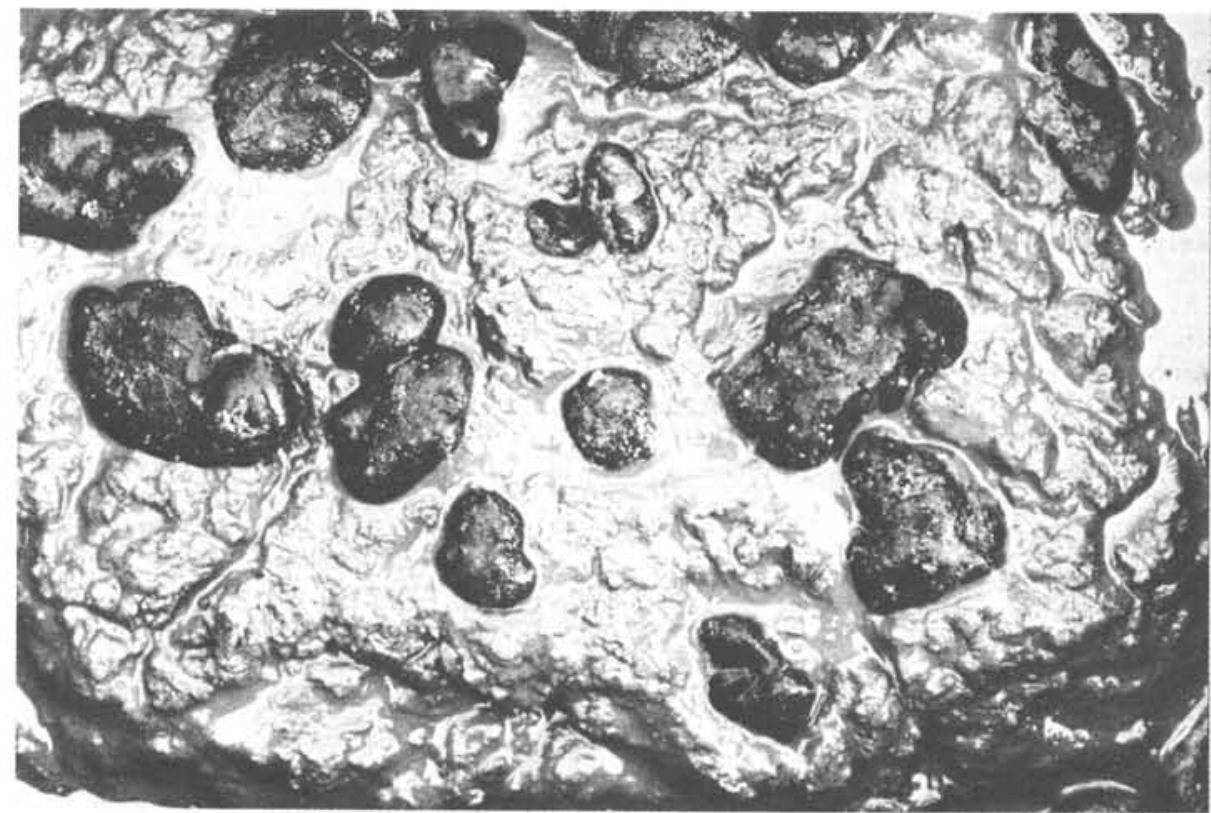

Figure 4: Box core surface from the eastern North Pacific with manganese nodules; the sediment is somewhat disturbed for technical reasons (VALDIVIA cruise 04, approximately $25 \times 35 \mathrm{~cm}$, photo courtesy D. Muller, Metallgesellschaft, Frankfurt). 
For scientists, these variations and unexplained features constitute a positive and exciting challenge; they must be related to nodule types, sizes, ages and formation mechanisms. For industry they represent negative factors, underlining the difficulties involved in predicting high grade nodule fields, the time and money needed for detailed exploration before minable reserves can be established.

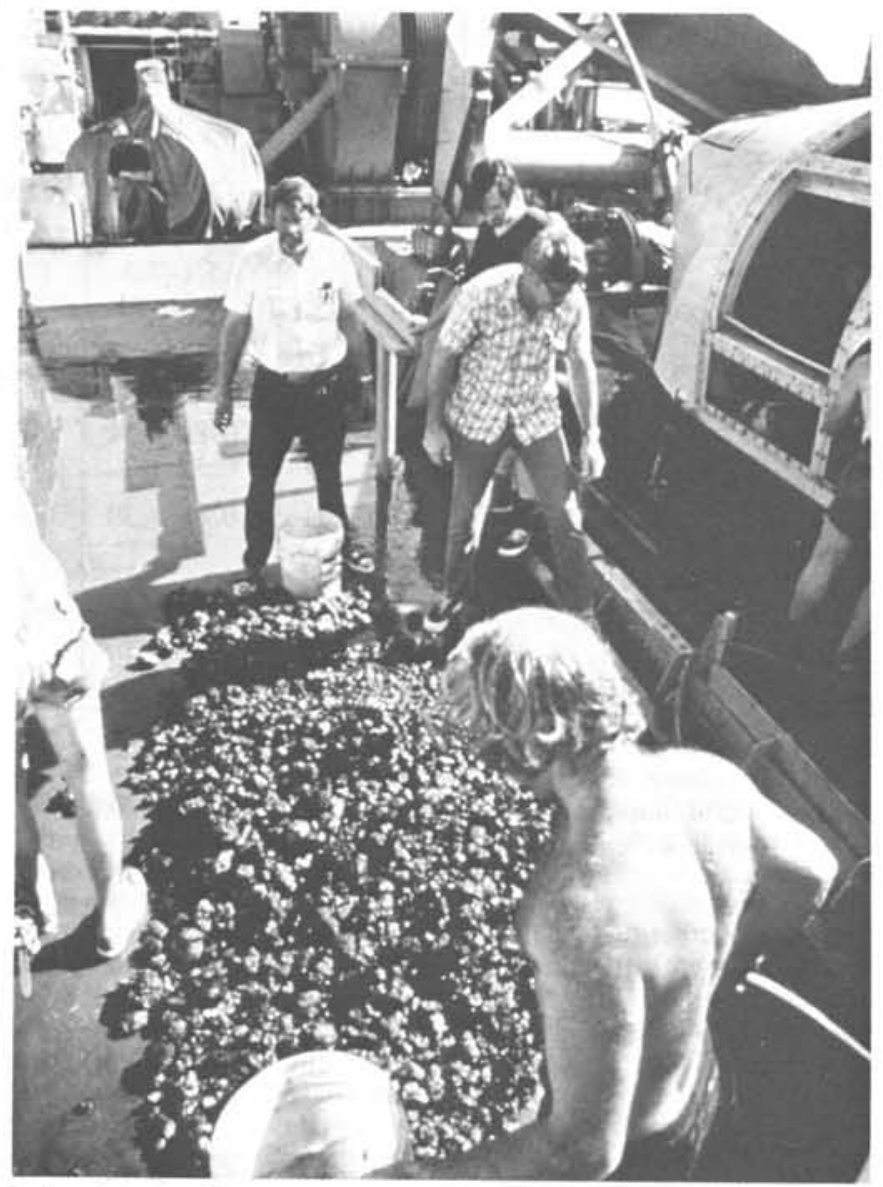

Scientists collect grab sampling of manganese nodules. (Photo courtesy David W. Pasho)

\section{Formation}

Metal supply to ferromanganese nodules and encrustations may be lithogenous, hydrogenous or biogenous. Encrustations on volcanic rocks and at least the outermost layers of exposed nodules prove that metals are transported by and accreted from seawater. Direct precipitation from true solutions seems unlikely, but organometallic complexes may be involved. Accretion from colloidal or very small particles of ferromanganese hydroxides is certainly an important mechanism, as indicated by the inclusion of clay minerals and terrigenous or biogenous particles in nodules. Sessile organisms on the nodules, such as foraminifera, porifera and hydroidea, may help to aggregate these particles. Scavenging of trace elements by hydroxides and clay minerals also appears to add them to the nodules.

Original sources of the metals are a) the continents and b) oceanic volcanoes. Mechanisms for obtaining metals in seawater include the alteration of volcanic rocks by hydrothermal solutions, which then transport the metals to the sea bottom waters, as has been observed in seamounts containing ferromanganese compounds from the FAMOUS area southwest of the Azores. In addition, volcanic rocks may be exposed to submarine weathering in cool waters at the surfaces or within oceanic layers. A third mechanism is the upward diffusion of metals in the pore water of sediments precipitated as floccules at the benthic boundary, or at contacts between different water masses; this was observed in the Baltic, for example. This mechanism is important at continental margins and probably also in the deep sea.

An increasing number of publications have indicated that nodules grow in the sediments too. Framboid nodules, or the lower mammilated and knobby parts of asymmetric nodules, are a case in point: metal sources here must be the sediments transported in pore waters. Organic matter content, together with sediment accumulation rates are important factors for these diagenetic processes. Little is known about them, partly due to the analytical difficulties and gaps in our knowledge about microbiological activities in these environments. The following problem might serve as an example: in interstitial waters of the uppermost few centimeters of sediments from the eastern equatorial Pacific, manganese is enriched with respect to sea water (Table 1, column 6) by a factor of 12-19. copper by 5-28, nickel by 2-6 (Hartmann and Muller, 1978). Mn/Cu ratios in these pore waters are about 1 , but in nearby nodules they are about 20-50, which indicates a chemical or biological fractionation. Diagenetic processes seem also to be responsible for the different enrichment factors of metals in nodules as compared to sediments (Table 1, columns 4 and 5). In short, then, nodule formation and metal uptake is a complex interplay of several processes.

Special problems are linked to the above-mentioned high grade zone in the eastern equatorial Pacific. Isolated high percentages of valuable metal contents have been reported from widely separated areas in the oceans. Nodules with more than $2 \%$ combined $\mathrm{Ni}, \mathrm{Cu}$ and $\mathrm{Co}$ are known to be northeast and south of Australia. In the South Pacific, nodules contain more than $1 \% \mathrm{Ni}$ in areas around $10-20^{\circ} \mathrm{S}$ and around $40^{\circ} \mathrm{S}$. But as mentioned above, at around $10^{\circ} \mathrm{N}$ these high Ni grades occur nearly continuously between $110^{\circ} \mathrm{W}$ and $180^{\circ} \mathrm{W}$ with associated $\mathrm{Cu}$ contents also commonly exceeding $1 \%$. Several factors seem to be important for these enrichments:

1. Biological productivity is high in the equatorial regime of near surface currents. Remains of planktonic organisms enriched in $\mathrm{Cu}$ or $\mathrm{Ni}$ reach the sea bottom and are partly dissolved on and in the sediments releasing these metals.

2. Partly Antarctic bottom water penetrates and possibly prevents high sedimentation rates, but favours transport and accretion of very fine material.

3. Sediment coring and drilling results from GLOMAR CHALLENGER show that at least in part of the area, several hiatuses exist in the Tertiary and Pleistocene. These results indicate erosion of fine deep sea sediments, leaving nodules as lag sediments; "fossil" nodules (Menard, 1976) may therefore be widespread. These seem to have high valuable metal contents too, pointing to a long-lasting continued positive balance of concentration processes, productivities, organic matter supply and sedimentation rates.

These ideas introduce the "nodule paradox", that is, that nodules are found on the sea bottom growing slowly at the rate of some millimeters to centimeters/million years, and are lying on sediments that are growing upward more rapidly at a rate of some millimeters/thousand years. Although the problem is still unsolved, current action is certainly involved, together with possible rolling by benthic organisms. Occasional turnover may explain some internal nodule structures. Nevertheless, many nodules could not have escaped being buried and some are, in fact, concentrated in definite layers within the sediments.

\section{Economic aspects}

In the 1960's, published estimates had manganese nodules totalling somewhere between 0.9 and $20 \times 10^{11} \mathrm{t}$ (Skornjakova and Zenkevich, 1961, and Mero, 1965). Combined with the discovery of some high grade nodules, they brought on an optimistic decade that was stimulating to both-science and industry. A recent bibliography (Meylan, et al., 1976) lists 315 publications on manganese 
nodules as appearing prior to 1959,764 from 1960-69 and 925 from 1970-75. The countries involved in these studies have been primarily the U.S.A., Japan, France, Germany, U.S.S.R., together with Australia, Canada, New Zealand and U.K. In 1974, Deep Sea Ventures Incorporated requested a claim of $60000 \mathrm{~km}^{2}$ near $15^{\circ} \mathrm{N} 126^{\circ} \mathrm{W}$ at a water depth of about $5000 \mathrm{~m}$ in the equatorial North Pacific, where most of the prospecting activities have been concentrated up to now. Another area which has been actively examined by CNEXO (France) is the South Pacific near Tahiti and the Marquesas Islands.

At present, prospecting for high grade nodules seems to be most promising in areas of high surface biological productivity, in depths where carbonate plankton remains are dissolved, and in regional or even local settings with sea bottom currents.

Investigations of present conditions are also important in evaluating possible environmental aspects of deep sea mining. U.S. panels (with governmental, academic and industrial representation) organized cooperative research on the Blake Plateau in 1970 and over the high grade nodule area of the eastern equatorial Pacific from 1969 to 1975 . These initial studies left many questions unanswered, but preliminary guidelines for minimizing the effect of deep sea mining on oceanic ecosystems were established (National Research Council, 1975). Most direct effects are foreseen for bottom dwelling communities on and in sediments and on nodules (Thiel, 1978). The "rain" of fine sediment during ascent of the mixture of sediments and nodules seems to be a minor problem, but surface discharge plumes of sea bottom water and suspension affect the ecosystem of the planktonic communities in the uppermost $100-200 \mathrm{~m}$ both physically and chemically. This may even be a benefit because of the addition of nutrients and the consequent increase in primary productivity. A group of experts (GESAMP, 1977) concluded thus: "Preliminary results suggest that no serious pollution will arise from manganese nodule mining activities at the scale presently projected". The group did, however, recommend the monitoring of full scale mining operations for final comments.

After the many variables, the scanty published data and the many unexplored areas mentioned above, it is nearly impossible to give a realistic appraisal of the current and future mineral potential of the nodules. As geologists, we have accumulated experiences in estimating mineral reserves and resources on land since the Middle Ages, yet it continues to be a difficult task and a permanent challenge. Even if all the geological prerequisites are met, deep sea mining costs will still be influenced by such factors as weather conditions and the technologies available for recovery. Nearly all of the

recovery systems, including airlift, hydraulic pumping, continuous line bucket dredging, are only at the experimental stage. The extractive metallurgy of nodules is a subject of continuing research (Fuerstenau and Han in Glasby, 1977); future legal requirements may further constrain current estimates.

Archer (1976) used different approaches to extract pertinent values of grades and abundances from published data, which, he assumed, are independent variables (this has recently been questioned: see Menard and Frazer, 1978), and then tried to define prime areas for further prospecting, as follows:

$$
\text { Ocean }
$$

Archer (1976) (million $\mathrm{km}^{2}$ )

$\begin{array}{lll}\text { North Pacific } & 4.2 & 6 \\ \text { South Pacific } & 1.0 & 6.8 \\ \text { Indic } & 0.5 & \\ \text { Atlantic and } & 0.85 & \\ \text { unexplored } & 6-7 & \\ \text { TOTAL } & & \end{array}$

(These figures are very approximate. The estimates by Mero are based on only three high grade samples. Sisselman (1975) estimates a total area of about 16 million $\mathrm{km}^{2}$ ). to be:

Prerequisites for first generation mine sites are thought

a) Minimum abundances of about $10 \mathrm{~kg}$ "wet" nodules $/ \mathrm{m}^{2}$ (i.e. about $15 \mathrm{~kg}$ dry nodules).

b) Combined contents of $\mathrm{Ni}+\mathrm{Cu}+\mathrm{Co}$ of more than $2 \%$ (or $\mathrm{Ni}+\mathrm{Cu}$ of about $1.76 \%$, assuming an average of $0.24 \%$ associated $\mathrm{Co}$ ).

c) Areal extent of fields of at least $20-30000 \mathrm{~km}^{2}$. This assumes an area of favourable relief, favourable engineering properties of underlying sediments, and lack of hard rock obstacles to give an operation life of at least 20 years. (Recoveries of 1-3 million $t$ dry nodules/year seem to be necessary, that is, at least 5000 wet $t /$ day).

These prerequisites would reduce the potential of the North Pacific by about $1 / 3-1 / 5$, that is roughly to $1-3$ million $\mathrm{km}^{2}$ (Archer, 1976) or 50-150 first generation mining sites.

Potential metal reserves for the North Pacific, based on all of these aspects are given in Table 2 (column 2). Estimates from Mero (in Glasby, 1977) are added in brackets and assume a similar total recovery of about $20 \%$. If improved technology and other factors will allow lower

\section{TABLE 2}

METAL RESERVES AND RESOURCES

\begin{tabular}{|c|c|c|c|}
\hline 1 & 2 & 3 & 4 \\
\hline & \multicolumn{2}{|c|}{$\begin{array}{c}\text { Manganese nodules North Pacific } \\
\text { high grade area }\end{array}$} & \multirow{2}{*}{$\begin{array}{l}\text { World reserves on } \\
\text { land (million } t, \\
\text { metals in situ) }\end{array}$} \\
\hline & Potential reserves & Resources & \\
\hline \multirow{2}{*}{$\begin{array}{l}\text { Minimum grade } \\
(\% \mathrm{Ni}+\mathrm{Cu}) \\
\text { Minimum abundance } \\
\text { (wet } \mathrm{kg} / \mathrm{m}^{2} \text { ) }\end{array}$} & 1.76 & 0.88 & \\
\hline & 10 & 5 & \\
\hline Total nodules (wet, billion $t$ ) & $24-57$ & $143-218$ & \\
\hline Assumed mining recovery (\%) & 22.5 & 45 & \\
\hline Processing recovery (\%) & 90 & 90 & \\
\hline \multicolumn{4}{|l|}{ Yields (million $t$ ) } \\
\hline $\mathrm{Ni}$ & $42-98(130)$ & $332-509$ & $44-68$ \\
\hline $\mathrm{Cu}$ & $34-80(104)$ & $275-422$ & $279-390$ \\
\hline $\mathrm{Co}$ & $9-20(23)$ & $?$ & $2.18-2.45$ \\
\hline $\mathrm{Mn}$ & $940-2200(2200)$ & $?$ & $722-5440$ \\
\hline
\end{tabular}


grades and abundances, a guess may be made as to what resources are likely to be workable at some time in the future (column 3).

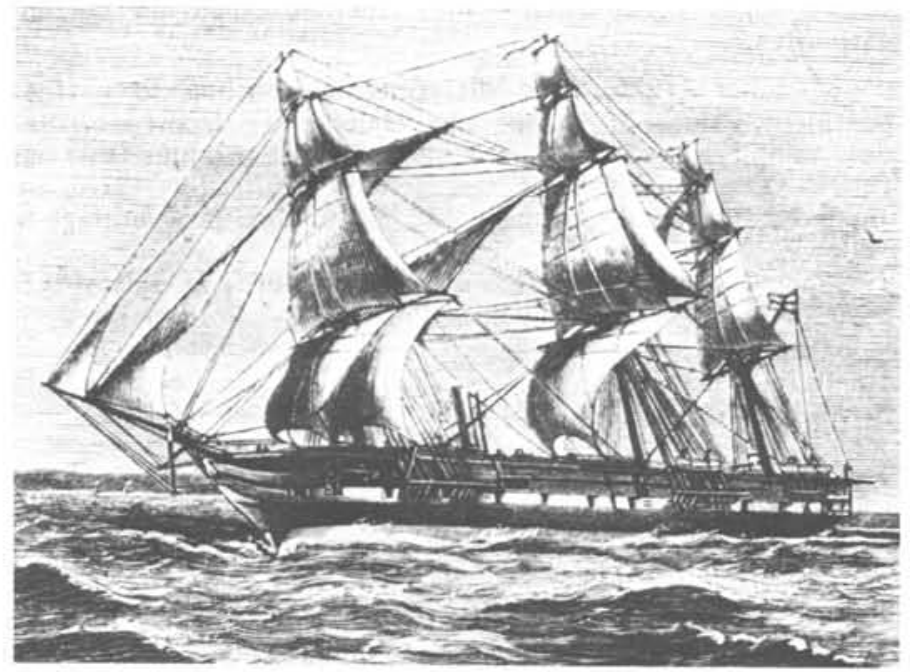

Woodcut of H.M.S. CHALLENGER, 1874 (from "Report on the Scientific Results of the Voyage of H.M.S. Challenger", 1885)

\section{References}

Even if all the figures from the nodule fields in Table 2 give only the order of magnitude estimates, the comparison with world reserves on land (column 4 ) is impressive.

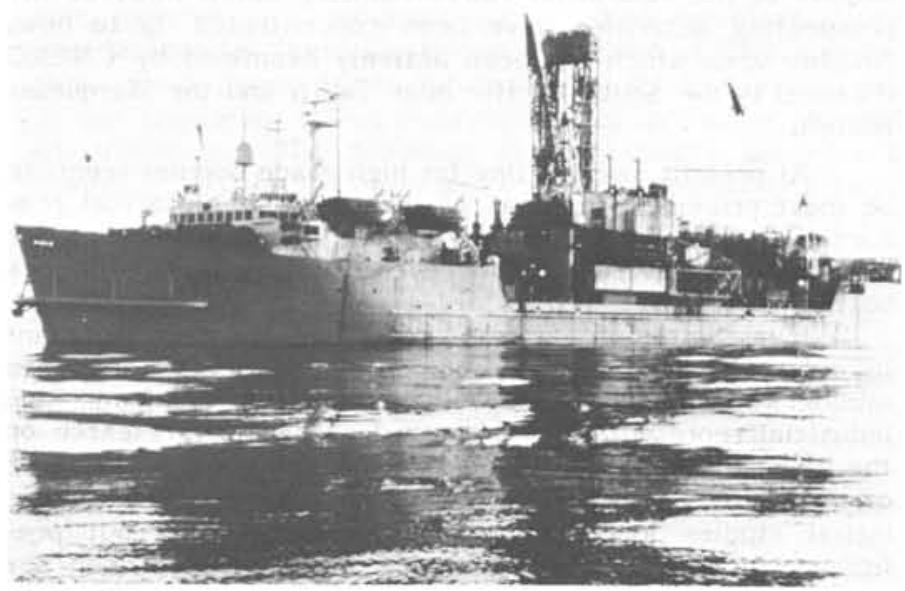

Typical of the vessels used today for deep sea mining, the SEDCO 445 was used by Ocean Management Incorporated in the first successful prototype seabed mining test at full ocean depth. (Photo courtesy David W. Pasho)
Archer, A.A., 1976, Prospects for the exploitation of manganese nodules: the main technical, economic an legal problems, in Glasby, G.P. and Katz, H.R. (eds.) 1976, Techn. Bull. 2, U.N. Econ. Soc. Corn. Asia Pacific, Committee for Coordination of Joint Prospecting for (Cineral Resources in South Pseific

Burns, R.G. and Burns, V.M.,1977, Mineratogy, in Glasby G.P. (ed.), 1977. Marine manganese deposits: Elsevier Oceanography Series, 15, Amsterdarn, $523 \mathrm{p}$.

Bezrukov, P.L., 1976, Ferromanganese nodules of the Pacifie Ocean: Transact. P.P. Shirshov Inst. Oceanology, Acad. Sci. U.S.S.R., v. 109, 302 p. (Russ.)

Buchanan. J.Y., 1881, On manganese nodules and their occurrence on the sea bottam: Chemical News, v. 44, $256 \mathrm{p}$.

Calvert, S.E., 1978, Ferrornanganese nodules on the deep sea floor: Metallurgist Material Technol., v. 10, p. 75.79 .

Cronan, D.S., Deep-Sea Nodules: Distribution and Geochemistry, in Glasby, G.P. (ed.), 1977, Marin manganese deposit:

Deacon, M., 1971, Scientists and the Sea, 1650-1900. A study of Marine Sciences: Acadernic Press, tondon, 445 P

Dreyfus-Rawson, M. and Ryan. W.B.F., 1978, Ocean floor sediments and polymetalti nodules (Map.): Lament sediments and polymetalific nodules (Map.

Elderfield, H.. The Form of Manganese and Iron in Marine Sediments, in Glasby, G.P. (ed.), 1977, Marine manganese deposits: Elsevier. Oceanography Series, 15.

Friedrich, C. (ed.), 1975, Geowissenschaftliche Untersuchungen auf dem Gebiet der. Manganknolienforschung: Bundesministerium Forschung. Technologie, Forsch. Berichte M 75-02., $199 \mathrm{pr}$

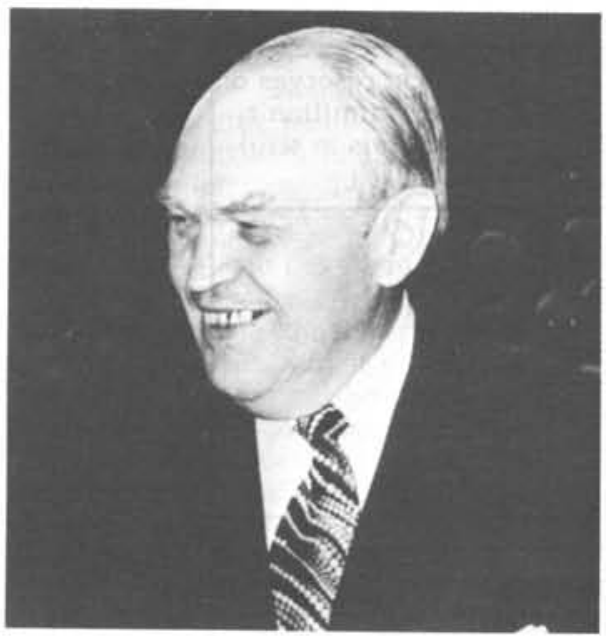

Friedrich, G., and Pluger, W.. 1974, Die Verteilung von Mangan, Eisen, Kobalt, Nickel, Kupfer und Zink in Manganknolien verschiedener Feider: Meerestechnik -mit-, v. 5, p. 203-206.

vuerstenov, D.W, and Han, K.N.. 1977. Extractive Metallurgy, in Glasby, G.P. (ed.), 1977. Marine manganese deposits: E.lsevier, Oceanography Series, is, Amsterdam, 533 p.

GESAMP, 1977, Scientific aspects of pollution arising from the exploration and exploitation of the Sea Bed: y, 7 , U.N., Reports and Studies, N. Y., 37 p.

Glasby, G.P. (ed.), 1977, Marine manganese deposits: Elsevier, Oceanography Series, v. Is, Amsterdarm, $523 \mathrm{p}$.

Gumbel, W., 1878, Uber die im stiflen Ozean auf dern Meeresgrunde vorkommenden Manganknollen: 5 itz, ber. bayer. Akad. Wiss. Math. Phys, K1., v. 8, p. 189-209.

Hartmann, M., and Muller, P.J., 1978, Trace metals it interstitial waters frotn Central Pacific Ocean sediprents, in: K.A. Fanning \& F. Mariheim (eds.): The

Menard, H.W.. 1976, Time. Chance and the Origin of Manganese Nodules: American Scientist, v. 64

Menard, H.W., and Frazer, J.Z., 1978, Manganese Nocules on the sea floor: Inverse correlation between grade and abundance: Science, v. 199, p. 969-971.

J.L., 1965. The Mineral Resources of the Seat Elsevier, Oceanography Series I, Amsterdam, $312 \mathrm{p}$

Meylan, M.A., Dugolinsky, B.K., and Fortin, L., 1976. Bibliography and index to literature on manganese nodules (1874-1975), IDOE-NSF Manganese Nodule Technical Report 14: Boulder, NOAA, Env, data serv, $433 \mathrm{p}$

Moore, T.C. Jr, and Heath, G.R., 1966, Manganese nodules, ropography and thichess of quaternary sediments in the Central Parific: Nature, v. 212, P. 983-985.

Murray, J.W. and Brewer, P.G.. Mechanisms of removal of manganese, iron and other trace metals from sea

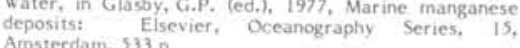

Murray, 3., 1876, Preliminary report on specimens of the sea bottoms Proc. R. Soc. London, v. 24, p. 471-532.

Murray, J, and Renard. A.F., 1891, Report on deep sea deposits based on the specimens coliected during the voyage of HMS Challenger: London, 525 p.

Murray, J. and Irvine, R., 1894, On the manganese oxides and manganese nodules in marine deposits: Trans. R. Soc. 721.742

National Research Council, 1975, Mining in the outer continental shelf and in the deep ocean: Nat. Acad. Sciences, Washington D.C.. $152 \mathrm{p}$.

Raab, W., 1972, Physical and chemical features of Pacifie deep sea manganese nodules and their implications to the genesis of nodules, in Horn, D.R. (ed.), Papers trorn aconterence on ferromanganese deposits on the ocean floor: Office IDOE, NSF, N.Y., p. 31-49.

Seibold, E.n 1973, Rezente submarine Metallogenese: Geol. Rundschau, v, 62, p. 641-684.

Shuitze-Westrum, H.H., 1973, The station and cruise pattern of R.V. "Valdivia" in relation to the variability of manganese nodule occurrences: Marine Technology $m i-$, v. 4, p. 163-167.

Sisselman, R., 1975, Ocean miners take soundings on legal problems, development alternatives: Eng. Min. J. ve. 176, p. $75-86$.

Skornjakova, M.S. and Zenkevich, N., 1961, The distribution of iron-manganese nodules in surficial sediments of the Pacific Ocean: Okeanologija, v. I, No.

Sorem, R.K. and Fewkes, R.H., 1977, Internal Charact. eristics, in Glasby, G.P., (ed.), 1977, Marine Manganese deposits: Elsevier, Oceanography Series, 13. Amsterdam, $523 \mathrm{p}$.

Thiel. H., 1978, The faunal environment of manganese hodules and aspects of deep sea time scales, in Krumbein. W.E. (ed.). Environmental Biogeochemistry and Geomicrobiology: Ann Arbor Science, v. 3, p. $887-896$.

Thomson, C.w., 1874, Preliminary notes on the nature of the sea bottom procured by the soundings of H.M.S. Chatienget during her cruise in the Southern Sea in the early part of the year 1870: Proc. R. Soc.

ABOUT THE AUTHOR: Professor Eugen Seibold has been Director of the Geological Institute at the University of Kiel since 1958, and has participated as a marine geologist on a number of cruises to the Indic and the Atlantic. As a member of IUGS's Commission of Marine Geology he organized several international symposia and participated as a Scientific Committee Member in the International Geological Correlation Programme from 1973 to 1977. 